\title{
Ramondo-Ostryetum carpinifoliae - a new association from the hop-hornbeam forests of the Sharri Mountains, Kosovo
}

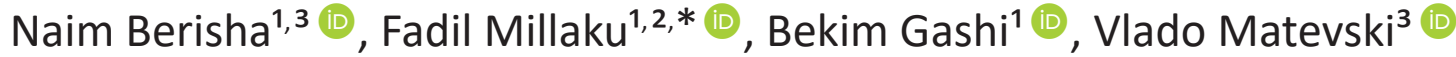

Key words: phytosociology, Ramonda, synsystematics, Sharri Mountains, Kosovo, RamondoOstryetum.

Ključne besede: fitocenologija, Ramonda, sinsistematika, Šar planina, Kosovo, RamondoOstryetum.
Received: 8. 10. 2018

Revision received: 15.2 .2019

Accepted: 17. 2. 2019

\begin{abstract}
In Europe, the genus Ramonda is represented with three species: Ramonda nathaliae, Ramonda serbica and Ramonda myconi. The first two are endemic Balkan species that are distributed also in Kosovo. These species grow in limestone as well as serpentine substrates, forming chasmophytic vegetation. The species Ramonda nathaliae is found in Macedonia, Greece, Serbia and in two localities in Kosovo, in the Sharri Mountains (Luboten and Gotovushë). R. nathaliae forms the following plant associations in the serpentines of Macedonia: Asplenio-Ramondetum nathaliae and Scorzonero-Ramondetum nathaliae, and the Achilleo-Ramondetum nathaliae in limestone substrates. Ostrya carpinifolia is charateristic species in Querco pubescentis-Ostryetum carpinifoliae, Ostryo-Fagetum, Querco-Ostryetum carpinifoliae and Corylo colurnae-Ostryetum carpinifoliae. This paper presents plant communities of Ramonda nathaliae and Ostrya carpinifolia in a limestone habitat, where the proposed new plant association named Ramondo-Ostryetum carpinifoliae ass. nova. is described. This plant community belongs to the class Quercetea pubescentis, order Quercetalia pubescenti-petraeae and alliance Fraxino orni-Ostryion. It was found and described on the limestone substrate on Mt. Luboteni (at 960-982 m a.s.l.).
\end{abstract}

Izvleček

Rod Ramonda ima v Evropi tri predstavnike: Ramonda nathaliae, Ramonda serbica in Ramonda myconi. Prvi dve vrsti sta balkanska endemita, ki sta razširjeni tudi na Kosovu. Vrsti uspevata na apnencu kot tudi na serpentinitu in gradita hazmoftsko vegetacijo. Vrsta Ramonda nathaliae je razširjena v severnem in srednjem delu Makedonije, severni Grčiji, jugovzhodni Srbiji in na dveh lokalitetah na Kosovu na Šari (Luboten in Gotovushë). $R$. nathaliae je značilna vrsta v Makedoniji v asociacijah na serpentinitu: Asplenio-Ramondetum nathaliae in ScorzoneroRamondetum nathaliae, ter na karbonatu Achilleo-Ramondetum nathaliae. Ostrya carpinifolia je značilna vrsta v asociaciji Querco pubescentis-Ostryetum carpinifoliae, v asociaciji Ostryo-Fagetum in asociacijah Querco-Ostryetum carpinifoliae ter Corylo colurnae-Ostryetum carpinifoliae. V članku predstavljamo rastlinske združbe vrst Ramonda nathaliae in Ostrya carpinifolia na karbonatu in novoopisano asociacijo Ramondo-Ostryetum carpinifoliae ass. nova. Združbo uvrščamo v razred Quercetea pubescentis, red Quercetalia pubescenti-petraeae in zvezo Fraxino orni-Ostryion. Opisana je bila na kabrbonatnem substratu na gori Ljuboten (med 960-982 m n.m.v) na Kosovu v bližini meje z Republiko Makedonijo.

1 Faculty of Mathematics and Natural Sciences, University of Prishtina, Kosovo.

2 Faculty of Agribusiness, University "Haxhi Zeka” Pejë, Kosovo.

3 Institute of Biology, Faculty of Natural Sciences and Mathematics, University of Ss. Cyril and Methodius, Skopje, Republic of North Macedonia.

* Corresponding author. Faculty of Agribusiness, University “Haxhi Zeka” Pejë. E-mail: fadil.millaku@uni-pr.edu 


\section{Introduction}

Poikilohydric plants have the unique ability of surviving in complete dehydration and are capable of fully recovering within a short period of time. This physiological phenomenon is very rare among vascular plants - only 300 plant species in the world (Porembski, 2011) and only five eudicots in Europe, all of which belong to the Gesneriaceae family, are known to have this special ability. These tertiary relict species are: Ramonda serbica Panč., $R$. nathaliae Panč. et Petrov., R. myconi (L.) Rchb., Haberlea rhodopenis Friv. and Jancaea heldreichii (Boiss.) Boiss, all of them remnants from the age when the European climate was warmer and more humid than today. During the Ice Age, these species found shelter in deep canyons and cliffs, places where they can still be found today.

Since their discovery in the $19^{\text {th }}$ century (Pančić 1874 , Petrović 1885), the Balkan Ramonda species were continuously studied from different biological and ecological aspects and have awakened the curiosity of researchers. The studied features include taxonomy, phytogeography, ecology, embryology and ecophysiology (Košanin 1921, 1939, Stefanoff \& Georgiev 1937, Micevski 1956, Quezel 1968, Meyer 1970, Janković \& Stevanovic 1981, Stevanović \& Stevanović 1985, Stevanović et al. 1986a, 1986b, 1987, 1991, 2014, Stevanović, 1986, 1989, Stevanović et al.
1992, Gashi et al. 2011, 2012a, 2012b, 2013a, 2013b). The Ramonda species and their various facets are continually being studied due to the curiosity that they attract.

In our study we were interested in the species of the genus Ramonda and their corresponding plant communities, in particular plant communities of $R$. nathaliae Panč. et Petrov. Out of three European species of the genus, two are Balkan endemics: Ramonda serbica Panč. and $R$. nathaliae Panč. et Petrov. These two species are characterized by their disjunctive distributional patterns - each having its own ecological characteristics. $R$. nathaliae is confined to the Republic of Macedonia, N. Greece, the slopes of the Sharri Mts. in Kosovo (Figure 1) and a few small localities in SE Serbia (Micevski 1956, Košanin 1921). The largest distributional range of $R$. serbica is in Albania, and it has also been reported for NW Greece, W Republic of Macedonia, SW and NE Montenegro, S and W Kosovo, SE and NE Serbia and NE Bulgaria (Rakić et al. 2014, Millaku et al. 2013, Stevanović et al. 1986). Even though they prefer limestone rocks, $R$. nathaliae has also been found on serpentine and granite substrates. As it prefers more open habitats and higher altitudes it is considered to be more tolerant than R. serbica. (Stevanović et al. 1991).

From the phytosociological point of view, $R$. nathaliae is represented in numerous plant communities in the Balkan

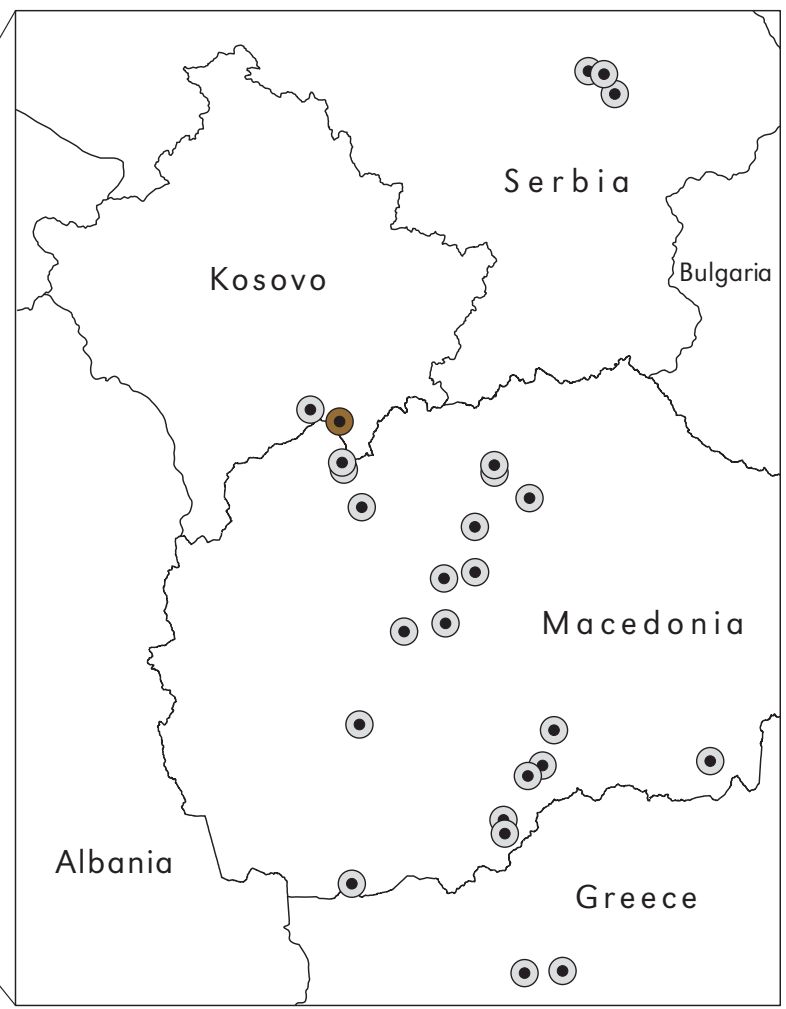


Peninsula. In Macedonia it forms three plant associations: Asplenio-Ramondetum nathaliae and Scorzonero-Ramondetum nathaliae on serpentine bedrock and Achilleo-Ramondetum nathaliae on limestone bedrock (Stevanović et al. 2014). They belong to the alliance Ramondion nathaliae Horvat ex Simon 1958, to which all chasmophytic vegetation of calcareous rock crevices in the alpine belt of the southern and central regions of the Balkans supposedly belongs (Horvat 1936). The reliability of such grouping is questionable (Stevanović et al. 2014) as there is vast ecological and floristic diversity within the chasmophytic groups that belong to this alliance, This issue therefore remains to be adequately addressed in future studies.

As the European hop-hornbeam (Ostrya carpinifolia Scop.) was recorded with great presence in the same studied environments we have to conclude that from the phytosociological point of view Ostrya carpinifolia Scop. belongs to two distinctive classes, and therefore forms three known plant associations in the Balkans. From the class Quercetea pubescentis Doing-Kraft ex Scamoni et Passarge 1959, order Quercetalia pubescenti-petraeae Klika 1933, alliance Fraxino orni-Ostryion Tomažič 1940 it forms the following two associations: Querco pubescentis-Ostryetum carpinifoliae Horvat 1938 and Corylo colurnae-Ostryetum carpinifoliae Blečić 1958. From the class Carpino-Fagetea sylvaticae Jakucs ex Passarge 1968, order Fagetalia sylvaticae Pawłowski 1928, alliance Aremonio-Fagion (Horvat 1950) Borhidi in Török et al. 1989, it forms the association Ostryo-Fagetum M. Wraber ex Trinajstić 1972.

The aim of our study is to provide phytosociological data on the new forest plant community that grows within the forest made primarily out of Ostrya carpinifolia and Ramonda nathaliae, and to determine the floristic and ecological features of known plant communities with $R$. nathaliae as well as those dominated by $O$. carpinifolia, absence of $R$. nathaliae, and finally to offer a discussion regarding the syntaxonomical position of this fragile and rare plant community.

\section{Material and methods}

Standard principles and methods of Zürich-Montpellier school (Braun-Blanquet 1964, Mueller-Dombois \& Ellenberg 1974) were applied. Plot sizes of $10 \times 10 \mathrm{~m}$ were used, resulting in 10 relevès. On each plot, a complete list of vascular plants was recorded, alongside with coverabundance values on a five-degree scale (Braun-Blanquet 1932). The diagnostic table (Table 1 ) offers all 10 relevès that represent the new plant association as described in this paper. The plant taxa nomenclature follows the Euro+Med Plant Base (Euro+Med 2006+). All relevès were made on limestone substrate, at altitudes ranging from 965 up to 979 m. a.s.l., at predominantly northern and north-western slopes of the Luboteni massif, the Sharri Mts. To facilitate the statistical analysis process we converted the standard Braun-Blanquet scale into ordinal numbers (Westhoff \& Maarel 1979) and used the TurboVeg (Hennekens \& Schaminée 2001) software to digitize and store the obtained data. In order to arrange and further analyse the relevès we used JUICE software (Tichý 2002). As integrated within JUICE, TWINSPAN analysis method (Hill 1979) was used to compare different associations and build a dendrogram. In order to assess the similarity between relevès from six other similar plant communities, we relied on NMDS plot analysis in $\mathrm{R}$ (R Core Team 2018) in comparing plant communities. All this fully integrated into JUICE software. The classification of taxa into life forms was performed according to Raunkiaer (1934), while the chorological types follow the chorological division of Europe as proposed by Oberdorfer (1990) and Pignatti (1982). The chorological spectrum of the new association and six similar plant associations were analysed and a detailed chorological and life form spectrum of the new plant association was made. Moreover, the studied community was compared to seven forest plant communities dominated by $O$. carpinifolia in the context of floristic composition and potential similarities concerning the community ecology, dominant life forms and chorological groups.

\section{Results and discussion}

After analysing the sampled phytosociological data and comparing the findings with other known relevant plant associations that had similar floristic and ecologic constitution, it was observed that association Ramondo-Ostryetum carpinifoliae represents an interesting forest plant community in the Sharri Mts. Its distinctive vegetation composition and corresponding habitat features have not been described until now. Below we describe its syntaxonomical hierarchical position:

\section{Ramondo-Ostryetum carpinifoliae ass. nova.}

Table 1, Relevé 8 holotypus hoc loco. Character taxa: Ostrya carpinifolia, Ramonda nathaliae, Euonymus latifolius, Saxifraga sempervivum, Cotoneaster tomentosus, Hieracium waldsteinii. Differential taxa: Arabis procurrens, Cytisus hirsutus, Bupleurum flavicans and Arenaria serpyllifolia. Dominant taxa: Ostrya carpinifolia and Ramonda nathaliae. Constant taxa: Ostrya carpinifolia, Ramonda nathaliae, Cotoneaster tomentosus, Asperula purpurea. 
Table 1: Association Ramondo-Ostryetum carpinifoliae ass. nova.

Tabela 1: Asociacija Ramondo-Ostryetum carpinifoliae ass. nova.

\begin{tabular}{|c|c|c|c|c|c|c|c|c|c|c|c|c|c|}
\hline & No. of relevé & 1 & 2 & 3 & 4 & 5 & 6 & 7 & 8 & 9 & 10 & & \\
\hline & Locality & 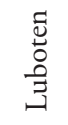 & 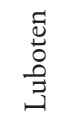 & 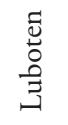 & 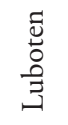 & 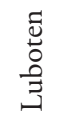 & 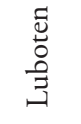 & $\begin{array}{l}\text { घ̃ } \\
0 \\
\stackrel{0}{\Xi}\end{array}$ & $\begin{array}{l}\bar{\Xi} \\
0 \\
\frac{0}{\Xi}\end{array}$ & $\begin{array}{l}\text { ए̃ } \\
0 \\
\stackrel{0}{\Xi}\end{array}$ & 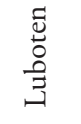 & & \\
\hline & Altitude (m) & 978 & 979 & 966 & 974 & 978 & 965 & 977 & 978 & 975 & 969 & & \\
\hline & Exposition & $\mathrm{N}$ & $\mathrm{N}$ & $\mathrm{N}$ & $\mathrm{N}$ & W & NW & $\mathrm{N}$ & $\mathrm{N}$ & $\mathrm{N}$ & $\mathrm{N}$ & & \\
\hline & Slope & 45 & 40 & 55 & 75 & 65 & 70 & 82 & 75 & 70 & 42 & & \\
\hline & Geological substratum & 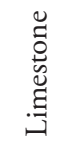 & 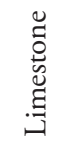 & 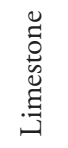 & 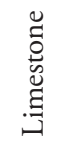 & 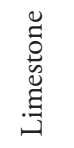 & 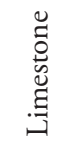 & 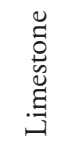 & 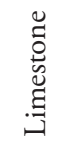 & 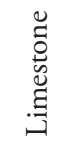 & 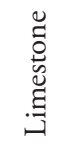 & & \\
\hline & Size of relevé $\left(\mathrm{m}^{2}\right)$ & 10 & 10 & 10 & 10 & 10 & 10 & 10 & 10 & 10 & 10 & Constancy & Floristic el. \\
\hline & Date & 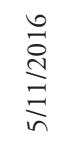 & 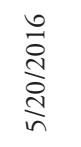 & $\begin{array}{l}\hat{D} \\
\stackrel{D}{D} \\
\frac{D}{n}\end{array}$ & $\begin{array}{l}\hat{\vec{D}} \\
\stackrel{i}{\hat{a}}\end{array}$ & 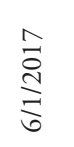 & & & 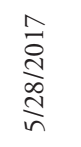 & & & & \\
\hline & Coordinates & 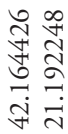 & 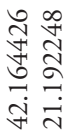 & 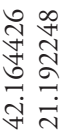 & 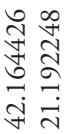 & 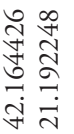 & 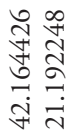 & 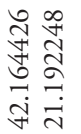 & 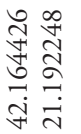 & 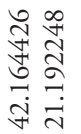 & 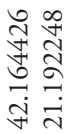 & & \\
\hline & Character species of Ass. & monde & Ostry & tum ca & rpinif & liae ass & nova & & & & & & \\
\hline $\mathrm{P}$ & Ostrya carpinifolia & 4 & 4 & 1 & 2 & 3 & 3 & 3 & 4 & 4 & 5 & V & Medit.mont. \\
\hline P shrub & Ostrya carpinifolia & + & . & 2 & 2 & 2 & 1 & . & 1 & . & . & IV & Medit.mont. \\
\hline $\mathrm{H}$ & Ramonda nathaliae & 2 & 4 & 3 & 3 & 3 & 4 & 4 & 4 & 4 & 1 & V & Balkan. \\
\hline $\mathrm{P}$ & Euonymus latifolius & + & + & . & . & 1 & 1 & . & 1 & 1 & + & V & Mediter.mont. \\
\hline $\mathrm{H}$ & Saxifraga sempervivum & + & 1 & & + & 2 & . & 1 & + & + & . & V & Balkan. \\
\hline $\mathrm{H}$ & Arabis procurrens & + & + & . & + & . & + & . & + & + & . & IV & Balkan. \\
\hline $\mathrm{P}$ & Cotoneaster tomentosus & + & 1 & 1 & + & + & 1 & + & 1 & 2 & + & V & S. Europe \\
\hline $\mathrm{Ch}$ & Asperula purpurea & 1 & . & 1 & . & 1 & 1 & + & 1 & 1 & + & V & SE Europe \\
\hline $\mathrm{Ch}$ & Cytisus hirsutus & 1 & . & + & . & 1 & 1 & 1 & + & . & . & IV & Eurosib. \\
\hline $\mathrm{H}$ & Hieracium pannosum & + & . & & . & + & . & . & . & . & . & I & Balkan. \\
\hline $\mathrm{T}$ & Bupleurum flavicans & 1 & . & . & . & + & . & + & . & . & + & III & Balkan. \\
\hline $\mathrm{H}$ & Centaurea stoebe & + & . & . & + & . & . & . & . & . & + & II & Centro-Europ. \\
\hline $\mathrm{H}$ & Euphorbia cyparissias & . & + & . & . & . & . & . & . & + & . & I & Centro-Europ. \\
\hline $\mathrm{P}$ & Fagus sylvatica & & . & . & . & & . & 1 & . & & + & I & Centro-Europ. \\
\hline P shrub & Juniperus communis & . & . & . & . & . & . & . & . & 1 & . & I & Circumbor. \\
\hline $\mathrm{H}$ & Asplenium ruta-muraria & . & . & . & . & . & . & + & . & + & . & I & Circumbor. \\
\hline $\mathrm{H}$ & Asplenium trichomanes & + & . & 1 & . & . & . & . & . & . & . & . & Cosmopol. \\
\hline $\mathrm{T}$ & Arenaria serpyllifolia & + & 1 & . & 2 & 2 & . & . & . & . & . & III & Euro-Asiat. \\
\hline $\mathrm{H}$ & Musci (Neckera crispa) & . & 2 & 1 & . & + & . & 1 & . & 2 & . & III & Euro-Asiat. \\
\hline $\mathrm{H}$ & Primula veris & . & . & . & . & . & . & + & . & . & . & I & Euro-Asiat. \\
\hline $\mathrm{H}$ & Viola sylvestris & . & . & . & . & & . & . & + & . & . & I & Euro-Asiat. \\
\hline $\mathrm{H}$ & Ceterach officinarum & . & + & . & . & . & + & . & . & . & . & I & Euro-Asiat. \\
\hline $\mathrm{H}$ & Sedum acre & & & 1 & 1 & 1 & & & & & & II & Euro-Cauc. \\
\hline $\mathrm{P}$ & Acer campestre & 1 & & + & & & & & & + & & II & Euro-Cauc. \\
\hline $\mathrm{H}$ & Hieracium pilosella & + & & & & & & & & & + & I & Euro-Cauc. \\
\hline $\mathrm{Ch}$ & Helianthemum canum & & 1 & & & & & & & & + & I & Euro-Cauc. \\
\hline $\mathrm{H}$ & Primula vulgaris & & & & & & & & + & & & I & Euro-Cauc. \\
\hline $\mathrm{Ch}$ & Teucrium chamaedrys & 1 & & 1 & 1 & & & + & & & & III & Euro-Med. \\
\hline
\end{tabular}




\begin{tabular}{|c|c|c|c|c|c|c|c|c|c|c|c|c|c|}
\hline & No. of relevé & 1 & 2 & 3 & 4 & 5 & 6 & 7 & 8 & 9 & 10 & & \\
\hline $\mathrm{T}$ & Calamintha acinos & + & & + & & & + & & & & & II & Euro-Med. \\
\hline $\mathrm{Ch}$ & Minuartia setacea & & & & & 1 & & & & & & I & Europ. \\
\hline $\mathrm{H}$ & Hieracium cymosum & & + & & & & & & & & & I & Europ. \\
\hline $\mathrm{H}$ & Fragaria viridis & . & + & . & 1 & . & + & . & 1 & + & . & III & Eurosib. \\
\hline $\mathrm{H}$ & Sedum telephium & . & + & & 2 & 2 & . & . & . & . & . & II & Eurosib. \\
\hline $\mathrm{H}$ & Hieracium murorum & . & . & . & . & + & . & + & . & . & . & I & Eurosib. \\
\hline $\mathrm{H}$ & Fragaria vesca & . & . & + & . & . & . & . & . & . & . & I & Eurosib. \\
\hline $\mathrm{H}$ & Leucanthemum vulgare & . & . & . & + & . & . & . & . & . & . & I & Eurosib. \\
\hline $\mathrm{H}$ & $\begin{array}{l}\text { Hieracium waldsteinii } \\
\text { Arabis alpina subsp. }\end{array}$ & 1 & . & . & + & . & + & 1 & . & + & . & III & Illyric \\
\hline $\mathrm{H}$ & caucasica & 1 & 1 & . & + & . & + & . & . & + & . & III & Medit. \\
\hline $\mathrm{H}$ & Aurinia corymbosa & . & . & + & . & . & . & . & + & . & . & I & Medit. \\
\hline $\mathrm{H}$ & Koeleria splendens & . & . & . & 1 & . & . & . & + & . & . & I & Medit.mont. \\
\hline P shrub & Rosa canina & . & . & + & 1 & . & . & . & + & + & . & III & Paleotemp. \\
\hline P shrub & Crataegus monogyna & + & . & . & . & . & . & . & + & + & . & II & Paleotemp. \\
\hline $\mathrm{T}$ & Bromus japonicus & + & . & . & . & . & . & . & . & . & . & I & Paleotemp. \\
\hline $\mathrm{P}$ & Fraxinus ornus & . & . & . & . & . & 1 & 1 & 1 & 1 & . & III & S. Europe \\
\hline $\mathrm{H}$ & Achnatherum calamagrostis & + & + & + & . & . & . & 1 & . & . & + & III & S. Europe \\
\hline $\mathrm{T}$ & Arabis turrita & 1 & . & + & . & . & . & + & 1 & . & . & III & S. Europe \\
\hline $\mathrm{H}$ & Scabiosa ochroleuca & 1 & + & . & . & + & . & + & . & . & . & III & S. Europe \\
\hline $\mathrm{H}$ & Trifolium montanum & 1 & . & & . & + & . & . & . & . & . & I & S. Europe \\
\hline $\mathrm{H}$ & Leontodon crispus & + & . & . & . & . & . & . & . & + & . & I & S. Europe \\
\hline $\mathrm{H}$ & Stipa pulcherrima & + & . & . & 1 & . & . & . & . & . & . & I & S. Europe \\
\hline $\mathrm{H}$ & Linaria concolor & & + & . & . & & . & . & . & & . & I & S. Europe \\
\hline $\mathrm{H}$ & Silene saxifraga & . & . & . & . & . & . & . & . & . & + & I & S. Europe \\
\hline P shrub & Quercus pubescens & . & . & 1 & . & . & . & . & . & . & . & I & SE Europe \\
\hline $\mathrm{H}$ & Helleborus odorus & . & 1 & + & + & . & . & . & . & . & . & II & SE Europe \\
\hline $\mathrm{T}$ & Sedum caespitosum & . & . & & + & 1 & + & . & . & . & . & II & Steno-Med. \\
\hline $\mathrm{Ch}$ & Teucrium polium & 1 & $\cdot$ & . & + & . & . & . & $\cdot$ & . & . & I & Steno-Med. \\
\hline G & Cyclamen hederifolium & . & . & 1 & . & . & . & . & . & + & . & I & Steno-Medit. \\
\hline
\end{tabular}

The syntaxonomic position:

Class: Quercetea pubescentis Doing-Kraft ex Scamoni et Passarge 1959

Order: Quercetalia pubescenti-petraeae Klika 1933

Alliance: Fraxino orni-Ostryion Tomažič 1940

Association: Ramondo-Ostryetum carpinifoliae ass. nova.

\section{General characteristics of the habitat}

The described plant community grows on the northern, north-western and rarely western slopes of the Mt. Luboteni massif (Figure 1), on the right side of the road Ferizaj - Glloboqicë, $52 \mathrm{~km} \mathrm{~S} \mathrm{from} \mathrm{Prishtina.} \mathrm{It} \mathrm{develops}$ at the altitudinal range from 965 up to $979 \mathrm{~m}$ a.s.l. All our relevés were made on a limestone substrate. The surveyed site was covered with trees and shrubs (Figure 2), while the general cover of the community ranged from $30-45 \%$. The plant association was characterized with a structure that is almost closed, developing on stable screes
(Figure 4), where populations of $R$. nathaliae were very dense.

\section{Floristic composition of the association}

The floristic composotion of the community is presented in the phytosociological table (Table 1) containing 10 relevés with a total of 56 species present. The species Asperula purpurea had a constancy level of $\mathrm{V}$, while the constancy level of Arabis procurrens and Ostrya carpinifolia as a shrub was IV. The species Arabis alpina subsp. caucasica, Achnatherum calamagrostis, Fragaria viridis, Teucrium chamaedrys, Fraxinus ornus, Arenaria serpyllifolia, Rosa canina, Bupleurum flavicans, Arabis turrita, Scabiosa ochroleuca and Musci (Neckera crispa) had a constancy level of III. It is important to emphasize that the following species were substrate tolerant: Asplenium trichomanes, Asplenium ruta-muraria, Leontodon crispus, Stipa pulcherrima, Koeleria splendens, Sedum acre and Clinopodium acinos. 


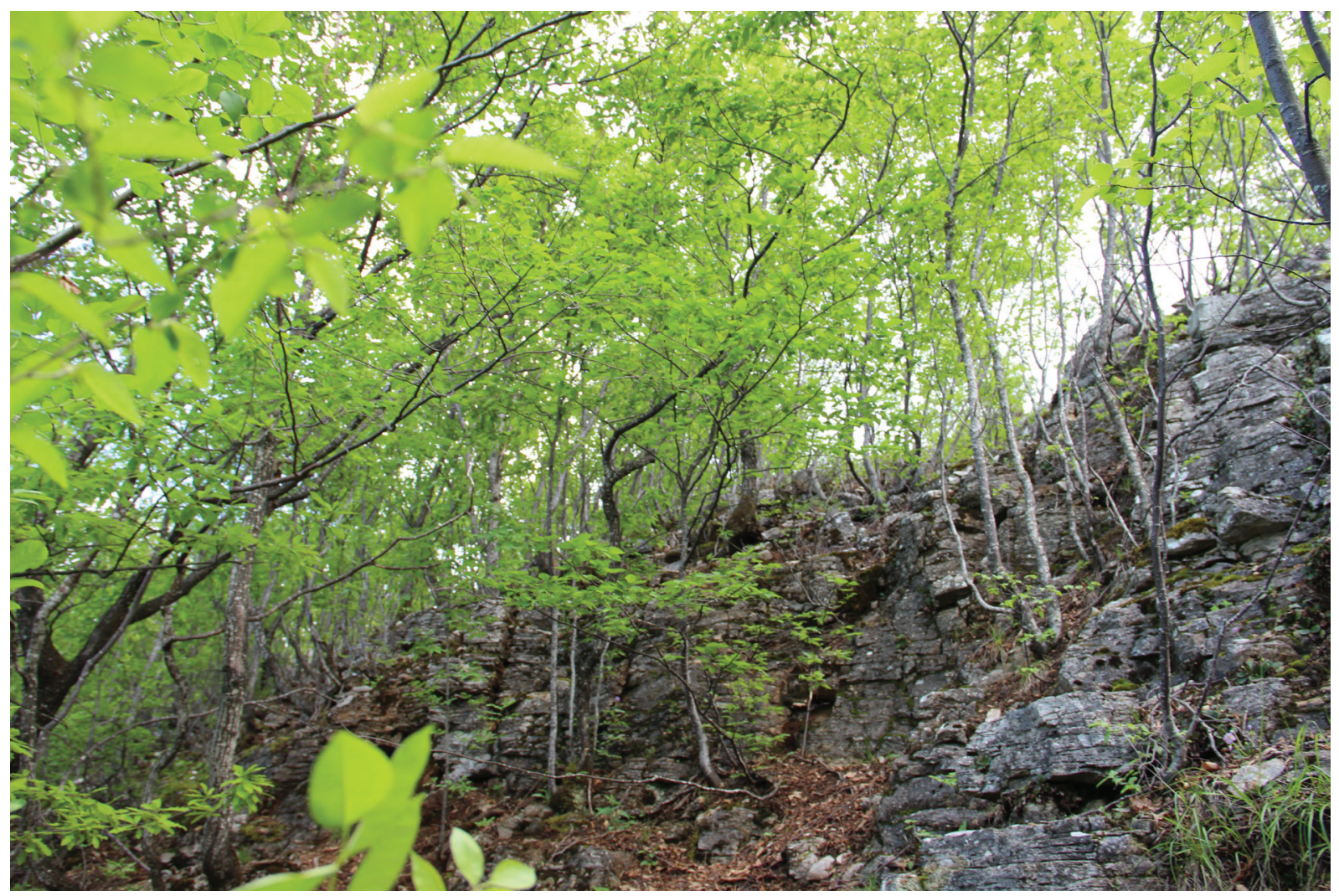

Figure 2: Typical appearance of the association Ramondo-Ostryetum carpinifoliae in Luboten on stable screes (Photo: F. Millaku, 2017). Slika 2: Tipičen videz sestojev asociacije Ramondo-Ostryetum carpinifoliae na Ljubotenu na stabilnem melišču (foto: F. Millaku, 2017).

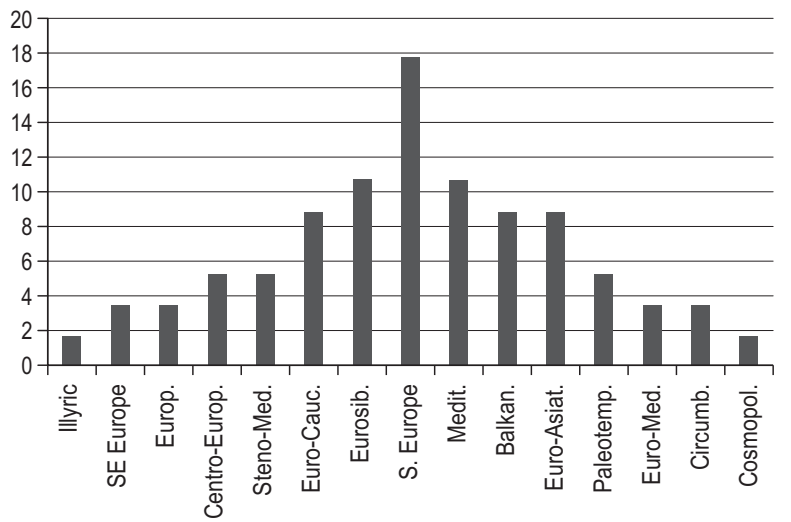

\section{Chorological spectrum}

The geographical position of this community can be illustrated through the spectrum of species distribution in terms of present geographical elements (Figure 3). The distribution of floristic elements of the community is: South-European 17.8\%, Mediterranean 10.7\%, European-Siberian 10.7\%, Balkan 8.9\%, European-Asiatic 8.9\%, European-Caucasian 8.9\%, Central-European 5.3\%, Steno Mediterranean 5.3\%, Paleotemperate 5.3\%, South-Eastern European 3.5\%, European 3.5\%, European-Mediterranean 3.5\%, Circumboreal 3.5\%, Illyric $1.7 \%$ and Cosmopolite $1.7 \%$. This chorological spectrum was compared with those from the six associations,

Figure 3: Geographical elements in the florsitic composition of the association Ramondo-Ostryetum carpinifoliae. Illyric 1.7\%, SE Europe (SouthEastern Europe) 3.5\%, Europ. (European) 3.5\%, Centro-Europ. (Central-European) 5.3\%, Steno-Med. (Steno Mediterranean) 5.3\%, Euro-Cauc. (European-Caucasian) 8.9\%, Eurosib. (European-Siberian) 10.7\%, S. Europe (South-European) 17.8\%, Medit. (Mediterranean) 10.7\%, Balkan 8.9\%, Euro-Asiat. (European-Asiatic) 8.9\%, Paleotemp. (Paleotemperate) 5.3\%, Euro-Med. (European-Mediterranean) 3.5\%, Circumb. (Circumboreal) $3.5 \%$, Cosmopol. (Cosmopolite) $1.7 \%$.

Slika 3: Geoelementi v floristični sestavi asociacije Ramondo-Ostryetum carpinifoliae. Ilyric (ilirski) 1,7\%, SE Europe (jugovzhodno evropski) 3,5\%, Europ. (evropski) 3,5\%, Centro-Europ (srednjeevropski) 5,3\%, Steno-Med. (stenomediteranski) 5,3\%, Euro-Cauc. (evropsko-kavkazijski) 8,9\%, Eurosib. (evropsko-sibirski) 10,7\%, S. Europe (južnoevropski) 17,8\%, Medit. (mediteranski) 10,7\%, Balkan (balkanski) 8,9\%, Euro-Asiat. (evropsko-azijski) 8,9\%, Paleotemp. (paleotemperatni) 5,3\%, Euro-Med. (evropsko-mediteranski) 3,5\%, Circumb. (cirkumborealni) 3,5\%, Cosmopol. (kozmopolitski) 1,7\%. 


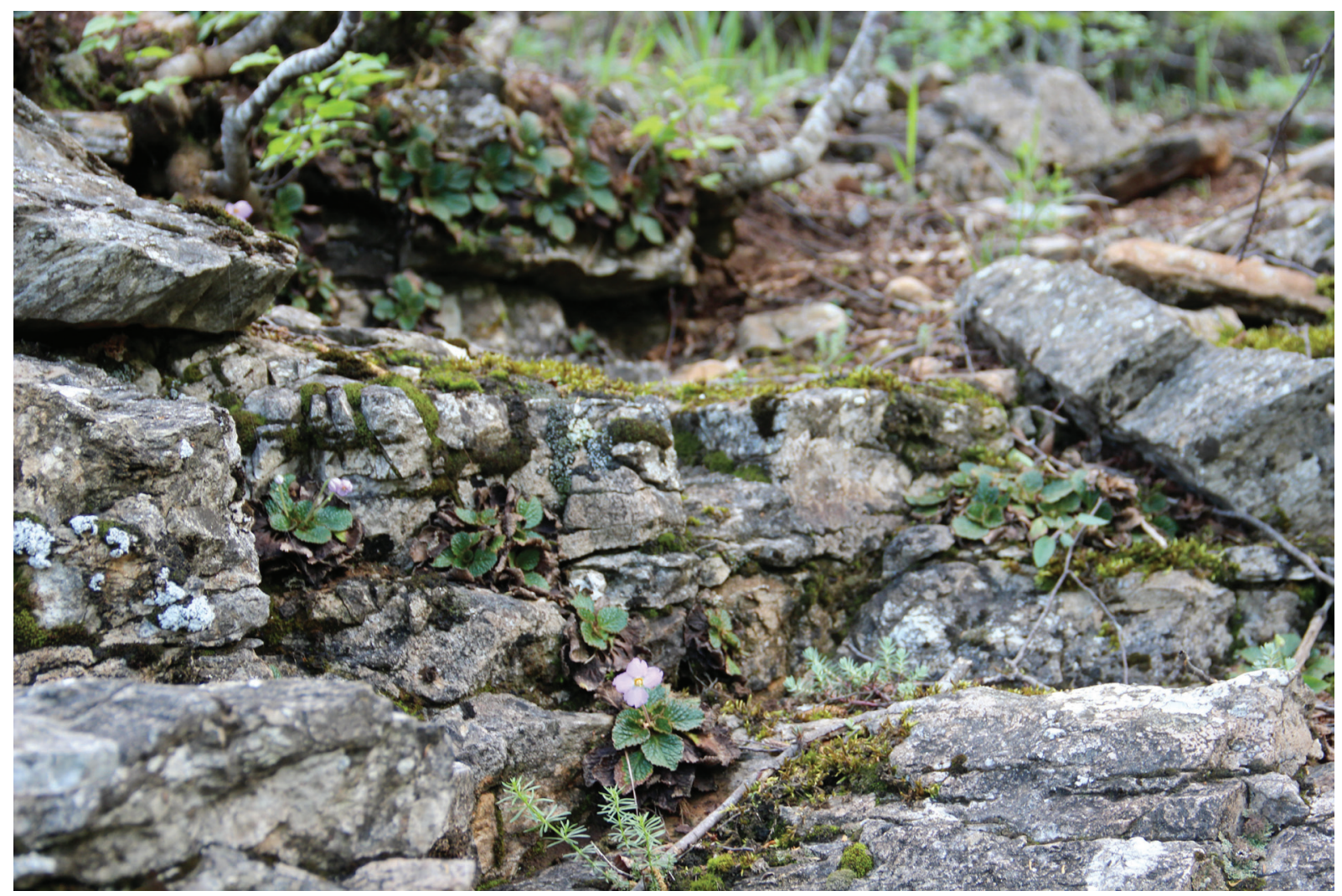

Figure 4: Ramonda nathaliae Pančić \& Petrović as seen on studied site, growing on limestone rocks and stable screes (Photo: F. Millaku, 2017). Slika 4: Ramonda nathaliae Pančić \& Petrović na preučevanem rastišču na stabilnem karbonatnem melišču (foto: F. Millaku, 2017).

and it was observed (Figure 8) that the Mediterranean mountain floristic element is clearly more pronounced, with many differences in other floral elements of the chorological spectrum.

In the Balkan chorological group, Ramonda nathaliae and Saxifraga sempervivum (with constancy class V) as well as Hieracium waldsteinii (with constancy class III) were the characteristic species of the association, while accompanying species from the same geoelement were: Arabis procurrens (IV), Bupleurum flavicans (III) and Hieracium pannosum (I).

In the Mediterranean chorological group (Medit. mont.) there were five species, two of them (Ostrya carpinifolia and Euonymus latifolius - both with constancy class V) were also the character species of the association Ramondo-Ostryetum carpinifolia.

The species Ramonda nathaliae, Saxifraga sempervivum and Hieracium waldsteinii from Balkan floristic elements and Ostrya carpinifolia and Euonymus latifolius from the Mediterranean mountain geoelement - as a character species of the association, contribute in giving this plant community a Balkan to Mediterranean montane character.

\section{Life form spectrum}

The studied plant community has a predominantly hemicryptophytic to phanerophytic character. The two main life forms (Figure 5) together constitute $77 \%$ of the whole life form spectrum of the association $(\mathrm{H}-33$ taxa $-59 \%$; P -10 taxa $-18 \%)$. The participation of chamaephytes (6 taxa $-11 \%)$ and therophytes (6 taxa$11 \%)$ is similar, while geophytes have one species only $(1.7 \%)$. It is worth noting that phanerophytes include 10 species, where $O$. carpinifolia is represented as a tree (P scap) as well as a shrub (P caesp), depending on the plant age. In total there are two trees (3.6\%) and eight shrubs (14\%). In this context, from the character species of the community, species $O$. carpinifolia, $C$. tomentosus and $E$. latifolius are all dominant species with constancy $\mathrm{V}$ while hemicryptophytes with constancy $\mathrm{V}$ comprise $R$. nathaliae, S. sempervivum and A. purpurea. One species has constancy IV and four constancy III. Chamaephytes have one species respectively for constancies V, IV and III, and the remaining three species with constancy I. Therophytes are represented with three species with constancy III, two species with constancy II and one species with 


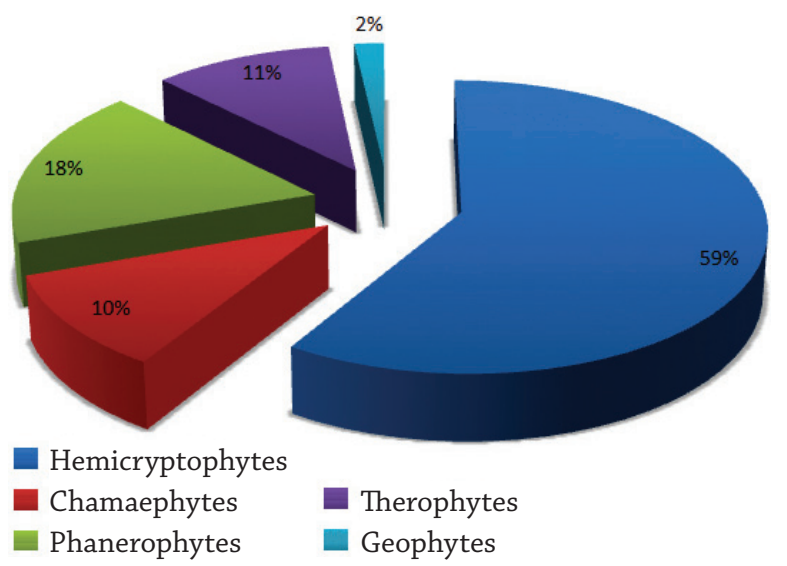

Figure 5: Life form spectrum of the association: Ramondo-Ostryetum carpinifoliae.

Slika 5: Spekter življenskih oblik asociacije Ramondo-Ostryetum carpinifoliae.

constancy I. in terms of the overall physiogonomy of the plant community, species $O$. carpinifolia as a tree as well as in the shrub formation covers all screes where $R$. nathaliae occurs.

\section{Comparisons with other similar plant communities with Balkan Ramonda species}

$R$. nathaliae populations can develop on calcareous as well as serpentine substrates, with preference for northexposed rocks, crevices and stable screes (Stevanović et al. 2014, Stevanović \& Matevski 2011, Stevanović \& Stevanović 1985). From conducted phytosociological studies in a sympatric area where $R$. nathaliae and $R$. serbica occurred together (Radovanski k., Serbia), it was reported that these two species can even establish a unique community: Ceterachi-Ramondetum serbicae ramondetosum nathaliae (Stevanović et al. 1987).

The population of the ass. Ramondo-Ostryetum carpinifoliae growing on limestone screes in the mountain massif of Luboten was covered with trees and shrubs of Ostrya carpinifolia. The differences observed between two serpentine plant communities (ass. Scorzonero-Ramondaetum nathaliae and ass. Asplenio-Ramondaetum nathaliae) and Ramondo-Ostryetum carpinifoliae are multiple. There are clear differences in floristic richness between the three plant associations.

The ass. Scorzonero-Ramondaetum nathaliae V. Stevanović \& V. Matevski (Stevanović \& Matevski 2011) has 54 species, of which only 7 are shared with RamondoOstryetum carpinifoliae. It was recorded on a serpentine substrate, at a far lower altitude ( $>700 \mathrm{~m}$ difference), with different character species and dissimilar community ecology. These differences can be easily seen on the
Naim Berisha, Fadil Millaku, Bekim Gashi \& Vlado Matevski

Ramondo-Ostryetum carpinifoliae - a new association from the hop-hornbeam forests of the Sharri Mountains, Kosovo
TWINSPAN dendrogram analysis (Figure 6) as well as in NMDS ordination (Figure 7), whereby we can conclud that it is probably more related to Asplenio-Ramondaetum nathaliae.

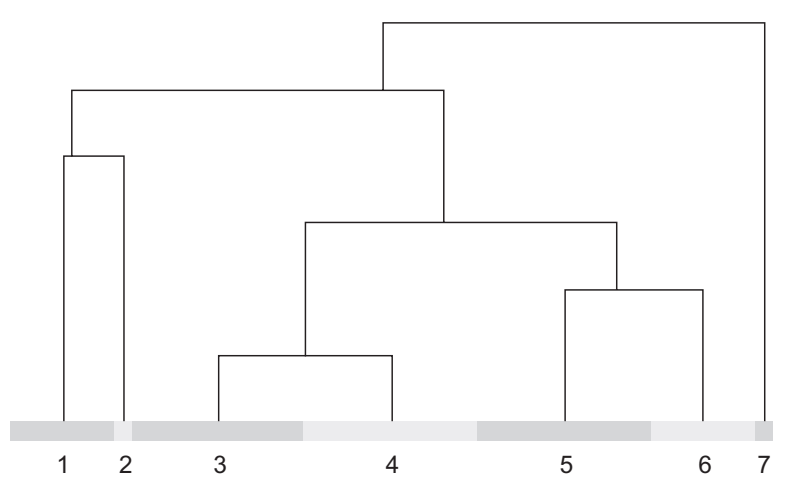

Figure 6: Dendrogram of cluster analysis between six most similar plant associations with Ramonda and the Ramondo-Ostryetum carpinifoliae.

Slika 6: Dendrogram klastrske analize šestih najbolj podobnih rastlinskih združb z vrstami rodu Ramonda in asociacije Ramondo-Ostryetum carpinifoliae.

1. Scorzonero-Ramondietum nathaliae, 2. Asplenio-Ramondietum nathaliae, 3. Ramondo-Ostryetum carpinifoliae, 4. Ceterachi-Ramondietum serbicae, 5. Valeriano tripterae-Ramondietum serbicae, 6. Musco-Ramondietum nathaliae, 7. Geranio-Ramondietum serbicae.

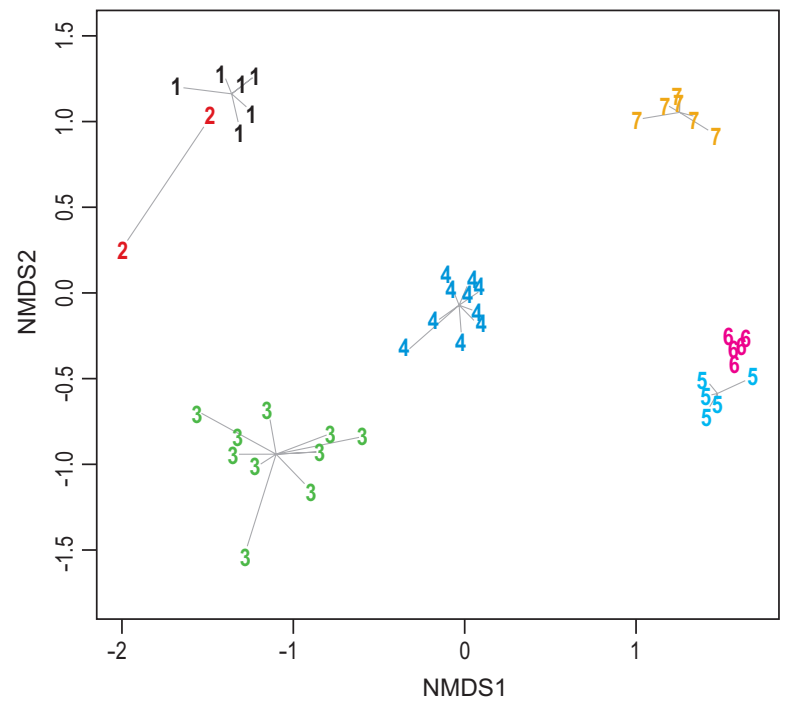

Figure 7: NMDS ordination plot analysis between the six compared most similar plant associations with Ramonda species and RamondoOstryetum carpinifoliae.

Slika 7: Ordinacijska analiza (NMDS) šestih najbolj podobnih rastlinskih združb z vrstami rodu Ramonda in asociacije Ramondo-Ostryetum carpinifoliae.

1. Scorzonero-Ramondietum nathaliae, 2. Asplenio-Ramondietum nathaliae, 3. Ramondo-Ostryetum carpinifoliae, 4. Ceterachi-Ramondietum serbicae, 5. Valeriano tripterae-Ramondietum serbicae, 6. Musco-Ramondietum nathaliae, 7. Geranio-Ramondietum serbicae. 
The Asplenio-Ramondaetum nathaliae V. Stevanović \& B. Stevanović 1985 (Stevanović \& Stevanović 1985) has 73 species, 9 of which are shared with Ramondo-Ostryetum carpinifoliae. In terms of species richness association is $23 \%$ richer than Ramondo-Ostryetum carpinifoliae. It also grows on serpentine substrate, at a lower altitude (>670 $\mathrm{m}$ difference), with different characteristic species and dissimilar community ecology. The existing differences between two of these $R$. nathaliae plant communities can be easily observed on TWINSPAN dendrogram (Figure 6) as well as on NMDS ordination (Figure 7). Due to the fact that this plant community is described based on only two relevès, the conducted non-metric multidimensional scaling shows one of its relevès (Figure 7) to be within the range of the Scorzonero-Ramondaetum nathaliae community.

The Ceterachi-Ramondetum serbicae R. Jov.-Dunj. 1952 ramondetosum nathaliae V. Stevanović et al. 1987. (Stevanović et al. 1987) has only 36 species registered from 10 relevès, and 11 of them are shared with RamondoOstryetum carpinifoliae. Nevertheless, except for $R$. nathaliae, all other shared species are accompanying ones from our described association. In this association the distinctive characteristic is the presence of two Ramonda species $(R$. nathaliae \& $R$. serbica) - which is not the case in our community. We see different character species and different ecological characteristics with no relevant conjunction in between. The TWINSPAN dendrogram analysis (Figure 6) and NMDS ordination (Figure 7) convincingly indicate their distinctiveness.

As suggested by its name, the Valeriano tripterae-Ramondietum serbicae Janković \& Stevanović (Janković \& Stevanović 1981) is a plant community characterized by Valeriana tripteris and Ramonda serbica, both of them absent in the ass. Ramondo-Ostryetum carpinifoliae. With only three species in common, differences are obvious in terms of the chorological spectrum (Figure 8) where the boreal floristic element is dominant in Valeriano tripteraeRamondetum serbicae. These two plant communities are clearly distinguishable also via the conducted TWINSPAN dendrogram (Figure 6) as well as in NMDS ordination (Figure 7).

The Musco Polypodio-Ramondetum serbicae Petković et al. 1988 is characterized by emphasized montane SouthEastern European floristic elements (Figure 8), which differs significantly from the representation of floristic elements in the ass. Ramondo-Ostryetum carpinifoliae. All character species of this association are absent in our studied plant community. Additionally, differences are obvious in floristic richness and disimilarities, 60\% fewer species than Ramondo-Ostryetum carpinifoliae, with only one shared species (Asplenium trichomanes). In addition to dendrogram showing clear differentiation (Figure 6), NMDS ordination (Figure 7) shows Musco PolypodioRamondetum serbicae to be closer with Valeriano tripteraeRamondetum serbicae.
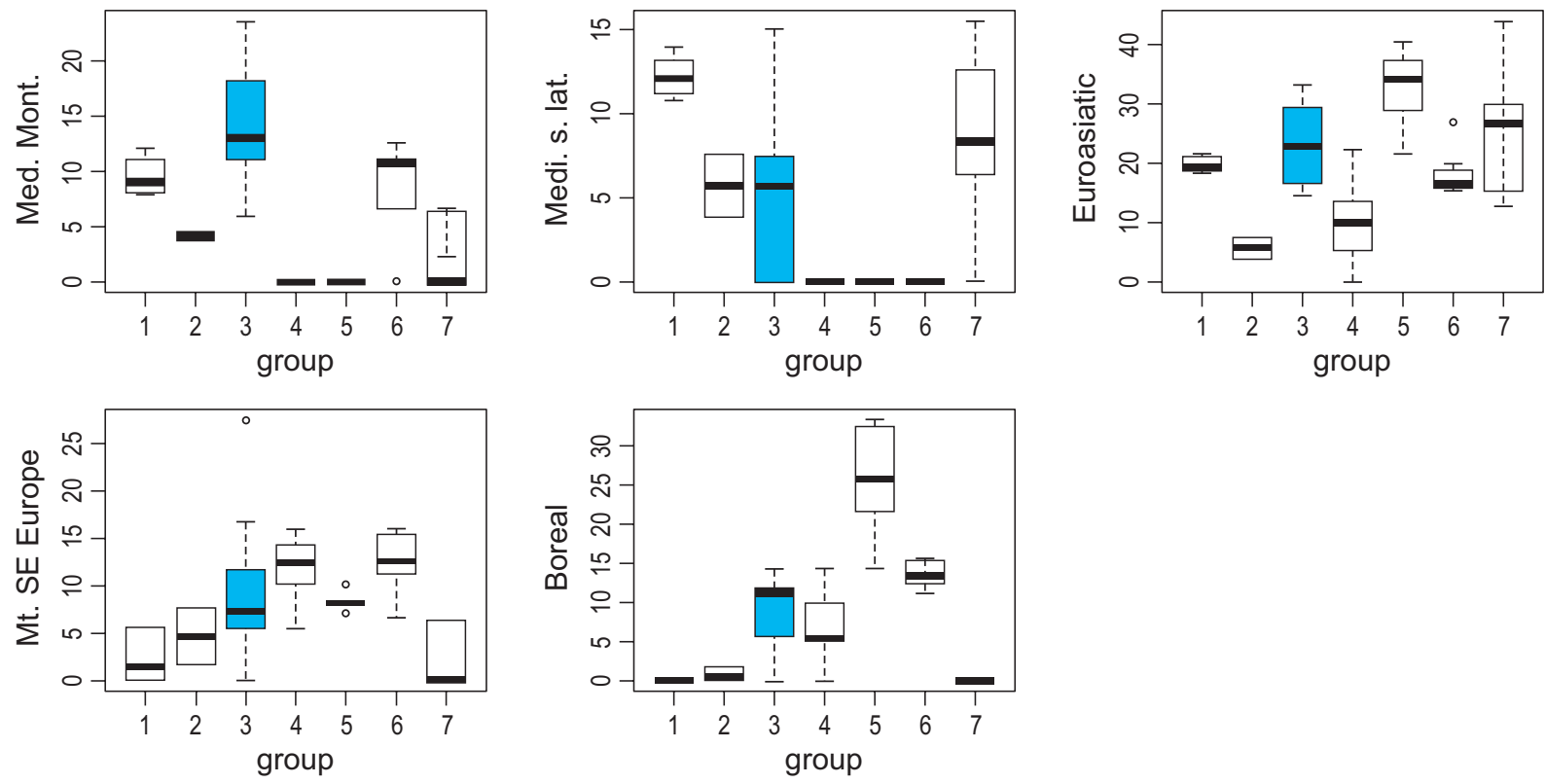

Figure 8: Chorological spectrum of the new association (in blue) in comparison to six most similar plant communities with Ramonda species. Slika 8: Primerjava horološkega spektra novopisane asociacije (modro) in šestih najbolj podobnih rastlinskih združb z vrstami rodu Ramonda. 1. Scorzonero-Ramondietum nathaliae, 2. Asplenio-Ramondietum nathaliae, 3. Ramondo-Ostryetum carpinifoliae, 4. Ceterachi-Ramondietum serbicae, 5. Valeriano tripterae-Ramondietum serbicae, 6. Musco-Ramondietum nathaliae, 7. Geranio-Ramondietum serbicae. 
The Geranio dalmatici- Ramondietum serbicae Stevanović \& Bulić 1992 is a predominantely hemocryptophytic (56\%) plant community and to some extent the presence of Euroasiatic floristic elements might be similar to the ass. Ramondo-Ostryetum carpinifoliae (Figure 8 ), which is the only similarity between them. It is very poor in species (31 species from 6 relevès) and has only three acompanying species in common with the ass. Ramondo-Ostryetum carpinifoliae. All character species are absent from one another. The NMDS ordination plot (Figure 7) shows a clear distance matrix between the two associations and the dendrogram of the cluster analysis (Figure 6) also shows the two clusters having high negative correlation value.

The prominent and constant presence of the tertiary relict and Balkan endemic species $R$. nathaliae makes this plant community unique among forest plant communities. Additionally, in comparison with similar forest plant communities (Table 2), due to the dominance of Ostrya carpinifolia and the constant presence of other diagnostic species like Primula veris, Primula vulgaris, Cotoneaster tomentosus and Fraxinus ornus as well as certain ecological factors, we concluded that this plant community syntaxonomically belongs to the class Quercetea pubescentis Doing-Kraft ex Scamoni et Passarge 1959. This plant community will not adhere into the anticipated alliance Ramondion nathaliae for the mentioned reasons. The practicability and accuracy of including the majority of chasmophytic plant communities from the Central Balkans into the alliance Ramondion nathaliae had been discussed before (Stevanović et al. 2014). Surely, further research is needed and the future results will bring new answers to the questions concerning the chasmophytic vegetation in the Balkans.

In all instances, the cluster dendrogram analysis (Figure 6) and the non-metric multidimensional scaling (NMDS) (Figure 7) clearly demonstrated the differentia- tion of the compared chasmophytic plant communities, in this context of the new ass. Ramondo-Ostryetum carpinifoliae in comparison with 6 other plant communities.

\section{Comparisons with typical Ostrya carpinifolia dominated forest communities from SE Europe}

O. carpinifolia as a native European species is usually found on steep slopes at higher altitudes, commonly in those zonal habitats where Quercus pubescens and Carpinus orientalis cannot grow normally. Since the ass. RamondoOstryetum carpinifoliae in addition to chasmophytic vegetation features had traits of a forest plant community, we compared it against the following seven plant communities with dominant $O$. carpinifolia:

1. Querco-Ostryetum carpinifoliae Horvat 1938

2. Seslerio-Ostryetum carpinifoliae Ht. et H-ić 1950

3. Corylo colurnae-Ostryetum Blečić 1958

4. Ostrya carpinifolia-Quercetum cerris Rexhepi \& Ružic ex. Matevski 2011

5. Querco pubescentis-Ostryetum carpinifoliae Horvat 1938

6. Seslerio robustae-Ostryetum Matevski 2011

7. Aceri-Ostryetum carpinifoliae B. Petković et al. 1986

1. Querco-Ostryetum carpinifoliae Horvat 1938 (Rexhepi 1983 ) is a typical forest plant community where predominant plants are trees and shrubs: $O$, carpinifolia, Q. pubescens, Fraxinus ornus, Cornus mas. This plant community has $90 \%$ more phanerophytes (Figure 9) than Ramondo-Ostryetum carpinifoliae and only 15\% shared species (Figure 11). In chorological terms, the most dominant groups were: S-Europ.-Sudsib. 20\%, Eurasiat. 15\%, Europ.-Caucas. 13\% (Figure 10) completely different from those in our studied community. Additional differences were obvious in terms of ecological preferences and overall species richness: + 40\% richer than Ramondo-Ostryetum carpinifoliae.

Table 2: Comparative overview of the forest Ostrya carpinifolia communities with the newly established community Ramondo-Ostryetum carpinifoliae.

Tabela 2: Primerjava gozdnih združb z vrsto Ostrya carpinifolia z novoopisano asociacijo Ramondo-Ostryetum carpinifoliae. 
Figure 9: Life form overview of corresponding forest communities. Slika 9: Pregled življenskih oblik obravnavanim gozdnih združb.

A. Ramondo-Ostryetum carpinifoliae,

B. Querco-Ostryetum carpinifoliae,

C. Seslerio-Ostryetum carpinifoliae,

D. Colurno-Ostryetum carpinifoliae,

E. Ostrya carpinifolia-Quercetum cerris,

F. Querco pubescentis-Ostryetum carpinifoliae,

G. Seslerio robustae-Ostryetum,

H. Aceri-Ostryetum carpinifoliae.
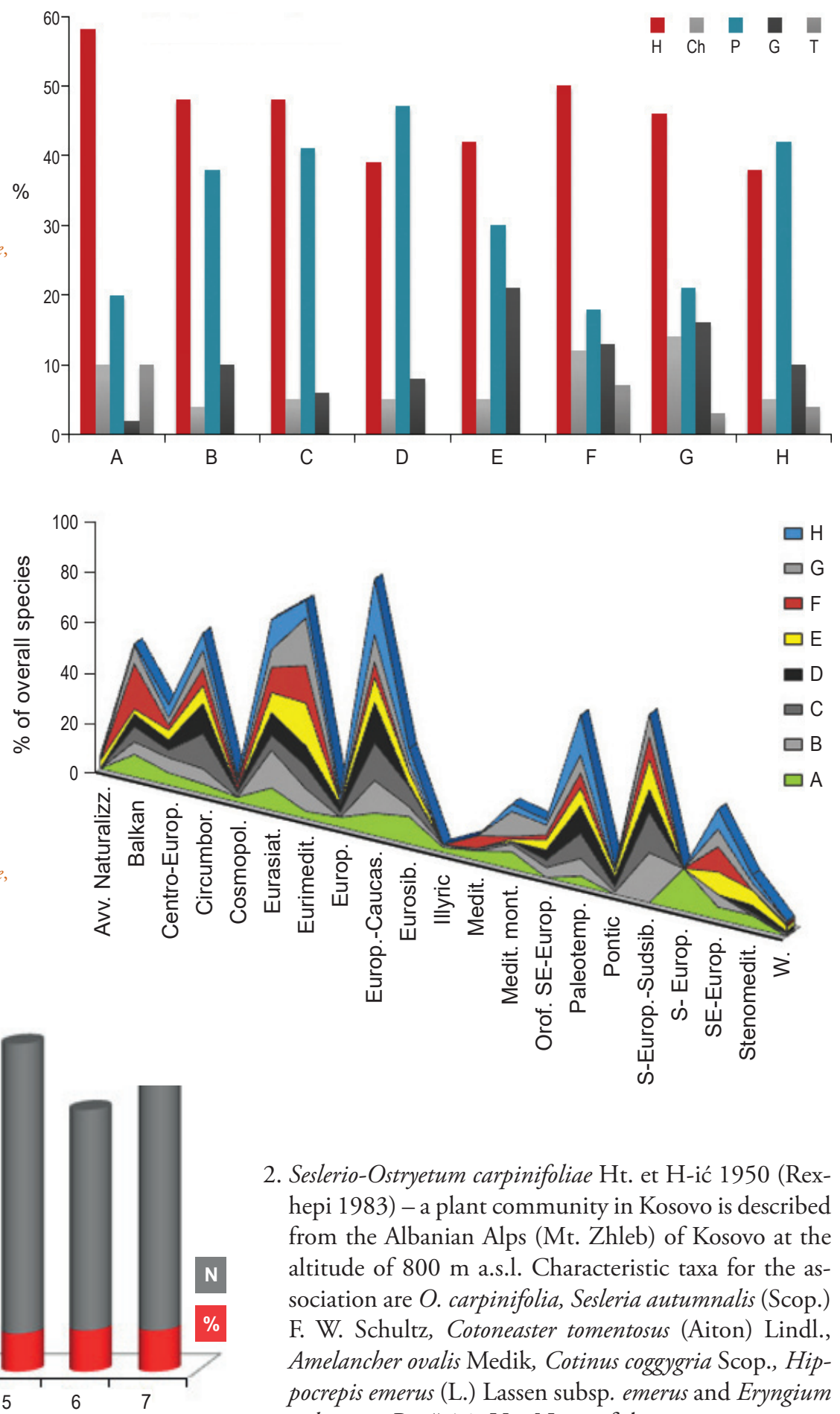

Figure 10: Overview of the chorological spectrum between the RamondoOstryetum carpinifoliae and corresponding forest Ostrya carpinifolia communities. Slika 10: Primerjava horoloških spektrov med asociacijo Ramondo-Ostryetum carpinifoliae in primerljivimi gozdnimi združbami z vrsto Ostrya carpinifolia.

A. Ramondo-Ostryetum carpinifoliae,

B. Querco-Ostryetum carpinifoliae,

C. Seslerio-Ostryetum carpinifoliae,

D. Colurno-Ostryetum carpinifoliae,

E. Ostrya carpinifolia-Quercetum cerris,

F. Querco pubescentis-Ostryetum carpinifoliae,

G. Seslerio robustae-Ostryetum,

$\mathrm{H}$. Aceri-Ostryetum carpinifoliae.

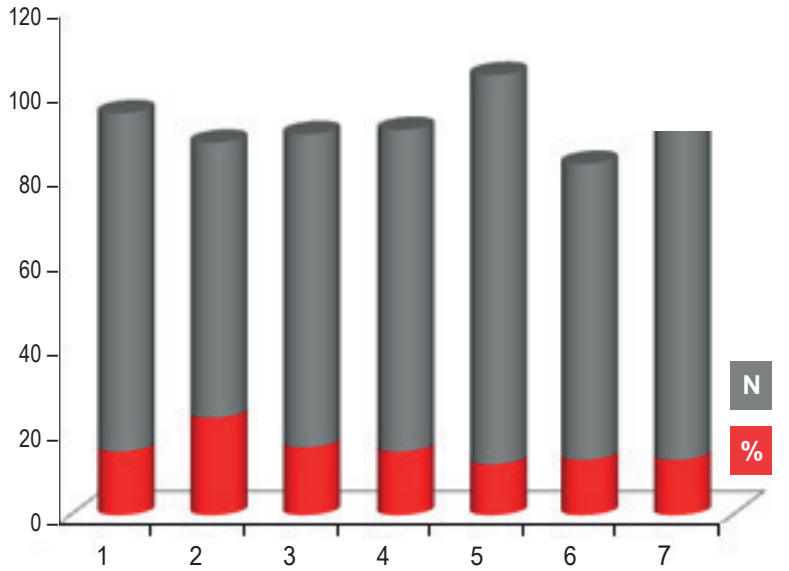

Figure 11: Species similiarity chart-compared to seven forest Ostrya carpinifolia communities. N-number of species, $\%$ - shared species. Slika 11: Graf vrstne podobnosti primerjanih gozdnih združb z vrsto Ostrya carpinifolia. N-število vrst, \% - skupne vrste.

1. Querco-Ostryetum carpinifoliae, 2. Seslerio-Ostryetum carpinifoliae, 3. Colurno-Ostryetum carpinifoliae, 4. Ostrya carpinifolia-Quercetum cerris, 5. Querco pubescentis-Ostryetum carpinifoliae, 6. Seslerio robustaeOstryetum, 7. Aceri-Ostryetum carpinifoliae.
2. Seslerio-Ostryetum carpinifoliae Ht. et H-ić 1950 (Rexhepi 1983) - a plant community in Kosovo is described from the Albanian Alps (Mt. Zhleb) of Kosovo at the altitude of $800 \mathrm{~m}$ a.s.l. Characteristic taxa for the association are O. carpinifolia, Sesleria autumnalis (Scop.) F. W. Schultz, Cotoneaster tomentosus (Aiton) Lindl., Amelancher ovalis Medik, Cotinus coggygria Scop., Hippocrepis emerus (L.) Lassen subsp. emerus and Eryngium palmatum Pančić \& Vis. None of these taxa are present in our association with $R$. nathaliae. Furthermore, 15 species $(23 \%)$ are shared (Figure 11), of which, with the exception of $O$. carpinifolia and $C$. tomentonsus, all other species are accompanying ones in both communities. As can be seen in Figure 9, the most dominant life forms are hemicriptophytes (48\%) accompanied by 
phanerophytes (42\%), whereas in Ramondo-Ostryetum carpinifoliae there were three times more hemicryptophytes than phanerophytes, which sufficiently explains the life form spectrum difference between them. Differences are clear also in chorological terms (Figure 10), with Europ.-Caucas.(15\%), Circumbor. (14\%) and S-Europ.-Sudsib. (14\%) being the dominant floristic groups here.

3. Corylo colurnae-Ostryetum Blečić 1958 (Rexhepi 1983) represents a very relic plant community with very heterogeneous composition that is additionally (Krasniqi 1972) believed to be of tertiary geologic period. They are ravine forests that develop in the transitional zones between oak and beech (Matevski et al. 2011), dominated by $O$. carpinifolia and Corylus colurna, the latter missing entirely in our studied community. Additionally, all of the diagnostic and constant species of the association are absent in the Ramondo-Ostryetum carpinifoliae, with only 12 similar species between them. Other major differences are observed in the chorological spectrum (Figure 10), with the Euro-Caucasian floristic element being the dominant one; as well as in the life form spectrum with dominant phanerophytes (47\%).

4. Ostrya carpinifolia-Quercetum cerris Rexhepi et Ružić ex. Matevski (Matevski et al. 2011) is a Quercus cerris dominated forest community developing on a carbonate bedrock. The differences with Ramondo-Ostryetum carpinifoliae are numerous also in this association. All of the diagnostic as well as constant species (with the exception of $O$. carpinifolia) are absent in the second. The dominant floristic element is Eurimediterranean (17\%) (Figure 10) and in terms of the life form spectrum, geophytes are $20 \%$ more represented here than in our studied community (Figure 9), so we concluded that these two plant communities are clearly distinguishable and different.

5. Querco pubescentis-Ostryetum carpinifoliae Horvat 1938 (Matevski et al. 2011) is a xerophilous forest community with O. carpinifolia and Q. pubescens. Only 11 species are shared with the analysed communities with two diagnostic species being the same. Anyway, in Ramondo-Ostryetum carpinifoliae, Q. pucescens was present only in one releve (1), and is not as important as it is in this community. Additionally, all other diagnostic and constant species are missing (Matevski et al. 2011). Differences between these two communities are clear also in terms of dominant floristic elements (Figure 10) and life forms (Figure 9).

6. Seslerio robustae-Ostryetum Matevski (Matevski et al. 2011) is a plant community of extreme steep slopes over carbonate bedrock. As its name suggests, the community is differentiated by the dominance of Sesleria robusta Schott \& al. Not only this dominant species, but also all of the diagnostic species are absent in Ramondo-Ostryetum carpinifoliae. Only 9 species are shared (Figure 11). In chorological terms (Figure 10) the dominant floristic element is Eurimediterranean, which is represented in the studied community with only $4 \%$.

7. Aceri-Ostryetum carpinifoliae Petković (B. Petković et al. 1986, Tomić 1980) - this plant community represents an azonal vegetation type that develops within mountain beech forests. The character species of the associations are: Cephalanthera rubra (L.) Rich., Cephalanthera damasonium (Mill.) Druce and Veronica austriaca subsp. teucrium (L.) D. A. Webb. The upper canopy is dominated by $O$. carpinifolia and $F$. ornus. With the exception of $O$. carpinifolia, none of the character and diagnostic species are present in RamondoOstryetum carpinifoliae. Out of 92 species, the compared communities share only 12. The dominance of phanerophytes (Figure 9) and the European-Caucasian floristic element dominating the chorological spectrum (Figure 10) of this association underline the differences between these two communities.

Table 2 gives a summarized comparative overview of seven forest-type plant communities with Ostrya carpinifolia and the differences that distinguish them from Ramondo-Ostryetum carpinifoliae.

Furthermore, it should be noted that calcareous rocky slopes of forest vegetation - including plant communities with Ramonda nathaliae, are known to harbour very specific flora that is worthy of protection. Calcareous rocky slopes with chasmophytic vegetation are recorded as habitat type 8210 (PAL.CLASS.: 62.1) according to Directive 92/43/EEC of the EU Commission (Anonymous 2013).

\section{Conclusions}

The new association Ramondo-Ostryetum carpinifoliae established in the Luboteni massif, the Sharri Mts., belongs to the forest plant communities of the alliance Fraxino orni-Ostryion Tomažič 1940 . These plant communities are rare and fragile, not only in this part of Kosovo but in the entire species range in the Balkans. They remain very interesting indeed for their rarity and endemism, and even more for the very specific habitats on deep and isolated gorges and canyons that they inhabit.

Additional studies into forest vegetation on limestone cliffs are needed and they will make new answers available with regard to syntaxonomic positioning and management of these interesting vegetation types. 
Consistent classification and monitoring of these habitats on a regional as well as European level could enhance the efforts towards their conservation, as they do represent very valuable, yet fragile biodiversity hotspots.

\section{Acknowledgements}

The authors would like to thank prof. Andraž Čarni (ZRC SAZU, Slovenia) and prof. Renata Ćušterevska (Institute of Biology, Macedonia) for their helpful comments and discussion while analyzing the obtained results of the initial manuscript. We are grateful to prof. Hazir Çadraku (UBT, Kosovo) for his help with the maps. We would also like to thank the two anonymous reviewers whose comments have greatly improved the initial manuscript.

Naim Berisha (D), https://orcid.org/0000-0002-4715-0263

Fadil Millaku (D), https://orcid.org/0000-0002-9392-9702

Bekim Gashi (D), https://orcid.org/0000-0003-0511-2733

Vlado Matevski (D, https://orcid.org/0000-0002-6818-3603

\section{References}

Anonymous 2013: Interpretation Manual of European Union Habitats. EUR28 - scientific reference document. European Comission.

Braun-Blanquet, J. 1932: Plant sociology: the study of plant communities. McGraw-Hill, New York.

Braun-Blanquet, J. 1964: Pflanzensoziologie. Grundzüge der Vegetationskunde. Springer-Verlag, Wien and New York.

Euro+Med 2006+ [continuously updated]: Euro+Med PlantBase the information resource for Euro-Med-iterranean plant diversity. - Published at http://ww2.bgbm.org/EuroPlusMed/ [accessed 01 Sep 2018]

Gashi, B., Abdullai, K., Mata, V., Misimi, V., Osmani, M. \& Kongjika, E. 2011: In Vitroculture -A tool to overcome the poor in vivo development of genus Ramonda plants. Bulletin of Natural Science. 536-543.

Gashi, B., Millaku, F., Abdullai, K., Daskalova, E., Dontcheva, S., Krasniqi, E., Mata, V. \& Kongjika, E. 2013b: Ecological and morphological characteristics and in vitro conservation of Ramonda serbica in Kosovo. Ekoloji. DOI: 10.5053/ekoloji.

Gashi, B., Abdullai, K. \& Kongjika, E. 2012b: Comparison of photosynthetic pigment contents of the resurrection plants Ramonda serbica and Ramonda nathaliae of some different populations from Kosovo, Albania and Macedonia. American Journal of Plant Science. doi:10.4236/ajps.2012.311192

Gashi, B., Abdullai, K., Mata, V. \& Kongjika, E. 2012a: Effect of giberellic acid and potassium nitrate on seed germination of the resurrection plants Ramonda serbica and Ramonda nathaliae. African Journal of Biotechnology. doi: 10.5897/AJB12.009
Gashi, B., Babani, F. \& Kongjika, E. 2013a: Chlorophyll fluorescence imaging of photosynthetic activity and pigment contents of the resurrection plants Ramonda serbica and Ramonda nathaliae during dehydration and rehydration. Physiology and Molecular Biology of Plants, 19(3), 333-341. doi:10.1007/s12298-013-0175-5

Hennekens, S. M. \& Schaminée, J. H. J. 2001: Turboveg, a comprehensive database management system for vegetation data. Journal of Vegetation 1Science 12: 589-591.

Hill, M. O. 1979: TWINSPAN. A fortran program for arranging multivariate data in an ordered two-way table by classification of individuals and attributes. Ecology and Systematics, Cornell Univ., Ithaca, New York.

Horvat, I. 1936: Istraživanje vegetacije planina Vardarske banovine II. Ljetop. JAZU 48: 211-227.

Janković, M. \& Stevanović, V. 1981: Contribution to the study of Ramonda serbica Panć. phytocoenoses in the gorges of the Šara mountain northern slopes. Ekologija (Beograd) 16: 1-34.

Janković, M. M. \& Stevanović, V. 1981: Prilog poznavanju fitocenoza sa srpskom ramondijom (Ramonda serbica Panč.) u klisurima severnih ogranaka Šarplanine. Ekologija 16(1): 1-34.

Košanin, N. 1921: La distribution gèographique des deux espèces de Ramondia du Balkan. Academie des Sciences et Arts de Belgrade, 34-49.

Košanin, N. 1939: Contribution to the biology of Ramonda nathaliae, $R$. serbica and Ceterach officinarum. Spomenik Srp. Kralj. Akad. LXXXIX, Prvi razred 20: 1-68.

Krasniqi, F. 1972: Šumska vegetacija brdskog regiona Kosova. Studije. Knj. 27. Prishtina.

Matevski, V., Čarni, A., Avramoski, O., Juvan, N., Kostadinovski, M., Košir, P., Marinšek, A., Paušič, A. \& Šilc, U. 2011: Forest vegetation of the Galičica mountain range in Macedonia. ZRC SAZU, Biološki inštitut Jovana Hadžija (SLO) \& Makedonska akademija na naukite i umetnostite (MKD).

Meyer, K. F. 1970: Gesneriaceaeals Glieder der Flora des Tertiär in Europa. Wiss. Ztschr. Friedrich-Schiller Univ. Jena. Math. Naturwiss. Reiche 19(3): 401-411.

Micevski, K. 1956: Eine Überprüfung der Verbreitungsgebite von Ramonda nathaliae Panč. et Petrov. und Ramonda serbica Panč. in Mazedonien und eine Zusammenfassung der karakteristischen Merkmalen der beiden Arten. Annuaire de la Faculté de Philosophie de l’Université de Skopje 9: 121-142.

Millaku, F., Rexhepi, F., Krasniqi, E., Pajazitaj, Q., Mala, Xh. \& Berisha, N. 2013: The Red Book of vascular flora of the Republic of Kosovo. MESP, Prishtina. ISBN: 978-9951-638-02-9.

Mueller-Dombois, D. \& Ellenberg, H. 1974: Aims and methods of vegetation ecology. Wiley, London.

Oberdorfer, E. 1990: Pflanzensoziologische exkursionsflora. Ulmer, Stuttgart.

Pančić, J. 1874: Flora of principality of Serbia. Belgrade.

Petković, B., Tatić, B., Marin P. \& Ilijin-Jug, M. 1988: Dve nove zajednice srpske Ramondije (Ramonda serbica Panć) u gornjem toku sliva reke Ibra. Glasnik Instituta za Botaniku Univerziteta u Beogradu, 22: $107-116$. 
Petković, B., Tatić, B., Marin, P. \& Ilijin-Jug, M. 1986: Nova reliktna zajednica Crnog graba sa javorovima (Aceri-Ostryetum carpinifoliae) na području jugozapadne Srbije. Glasnik Instituta za botaniku i botaničke bašte Univerziteta u Beogradu. Tom. XX, 55-64.

Petrović, S. 1885: Ramondas in Serbia. Glasnik srpskog učenog društva (Belgrade) 62, 101-123.

Pignatti, S. 1982: Flora d'Italia, 1-3. Edagricole, Bologna.

Porembski, S. 2011: Evolution, Diversity, and Habitats of Poikilohydrous Vascular Plants. Plant Desiccation Tolerance Ecological Studies, 139-156. doi:10.1007/978-3-642-19106-0 8

Quezel, P. 1968: Signification phytosociologique des Gèsnèriaces Grecques. Collectanea Botanica 7: 947-973.

R Core Team 2018: R: A language and environment for statistical computing. R Foundation for Statistical Computing, Vienna, Austria. http://www.R-project.org/.

Rakić, T., Lazarević, M., Jovanović, Ž. S., Radović, S., Siljak-Yakovlev, S., Stevanović, B., \& Stevanović, V. 2014: Resurrection plants of the genus Ramonda: Prospective survival strategies - unlock further capacity of adaptation, or embark on the path of evolution? Frontiers in Plant Science. doi: 10.3389/fpls.2013.00550

Raunkiaer, C. 1934: The life-forms of plants and statistical plant geography. Clarendon Press, Oxford, UK.

Rexhepi, F. 1983: Šumske fitocenoze sa crnim grabom (Ostrya carpinifolia Scop.) na području Kosova. - ANUBiH., Knjiga 21: 479-486.

Stefanoff, B. \& Georgiev, T. 1937: Ramondia serbica Panč. in Bulgaria. Annuairede l'Université de Sofia 15(2): 42-53.

Stevanović, V. \& Matevski, V. 2011: Hazmofitske zajednice endemoreliktne vrste Ramonda nathaliae Panćič \& Petrović na serpentinitima Makedonije. Proceedings of the conference - Nature Protection in $21^{\text {st }}$ Century. 20-23 September, Zabljak, Montenegro. p. 916.

Stevanović, V., Niketić, M. \& Stevanović, B. 1987: Fitocenološke karakteristike simpartićkih staništa endemo-reliktnih vrsta Ramonda serbica Panć. i $R$. nathaliae Panć. et Petrov. Glasnik Instituta za Botaniku Univerziteta u Beogradu, 21: 18-26.

Stevanović, B. 1986: Ecophysiological characteristics of the species Ramonda serbica Panć. and $R$. nathaliae Panć. et Petrov. Ekologija (Beograd) 21:119-134.
Stevanović, B. 1989: Water relations of Ramonda serbica Panć. and $R$. nathaliae Panć. et Petrov. in different habitat conditions. Glasnik Instituta za Botaniku Univerziteta u Beogradu 23, 47-55.

Stevanović, B., Pham Thi, A. T., Monteiro da Paula, F. \& Viera da Silva, J. 1992: Effect of dehydration and rehydration on the polar lipid and fatty acid composition of Ramonda species. Can. J. Bot. 70: $107-113$.

Stevanović, V. \& Stevanović, B. 1985: Asplenio cuneifolii-Ramondaetum nathaliae - new chasmophytic community on serpentine rocks in Macedonia. Bull. Mus. Hist. Nat. Belgrade B 40: 75-87.

Stevanović, V. \& Bulić, Z. 1992: New data on chorology and phytocenology of species Ramonda serbica Panć. (Gesneriaceae) in Montenegro. Glasnik, 25: 7-16.

Stevanović, V., Jakovljević, K. \& Matevski, V. 2014: Chasmophytic communities of endemic and relict species Ramonda nathaliae Pančić \& Petrović on ophiolithic substrate in Republic of Macedonia. Botanica Serbica. 38 (1): 81-90.

Stevanović, V., Niketić, M. \& Stevanović, B. 1986a: On distribution of endemicand relic species Ramonda serbica Panć. in SR Macedonia. Glasnik Prirodnjaćkog Muzeja u Beogradu. Ser. B. 41: 89-95.

Stevanović, V., Niketić, M. \& Stevanović, B. 1986b: Sympatric area of the sibling and endemo-relic species Ramonda serbica Panč. and $R$. nathaliae Panč. et Petrov. (Gesneriaceae) in southeast Serbia (Yugoslavia). - Glasnik Instituta za botaniku i Botaničke bašte Univerziteta u Beogradu, 20: 45-54.

Stevanović, V., Niketić, M. \& Stevanović, B. 1991: Chorological differentiation of the endemic and relic species Ramonda serbica Panč. and $R$. nathaliae Panč. et Petrov. (Gesneriaceae) on the Balkan Peninsula. - Bot. Chron. 10: 507-515.

Tichý, L. 2002: JUICE, software for vegetation classification. Journal of Vegetation Science 13: 451-453.

Tomić, Z. 1980: Fitocenoze crnoga graba (Ostrya carpinifolia Scop.) u Srbiji. Beograd, Ph. D. Thesis, University in Belgrade.

Westhoff, V. \& Maarel, E. 1973: The Braun-Blanquet's approach. In: Whittaker, R. (ed.): Handbook of Vegetation Science. Ordination and Classification of Vegetation. The Hague, p. 619-726. 